2. To: (Receiving Organization)

Distribution

5. Proj./Prog./Dept./Div.:

FFTF PTant
3. From: (originating organization)

S. W. Hiller

6. Design Authority/ Design Agent/Cog. Engr.:

S. W. Hiller

\section{Originator Remarks:}

Work plan describes the program and controls for the development testing of the OTA Shear equipment.

11. Receiver Remarks: 11A. Design Baseline Document? [] Yes [X] No

4. Related EDT No.:

$N / A$

7. Purchase order No.:

$N / A$

9. Equip./Component No.: $\mathrm{N} / \mathrm{A}$

10. System/Bldg./Facility: FFTF

12. Major Assm. Dwg. No.: $N / A$

13. Permit/Permit Application No.: N/A

14. Required Response Date: JuTy 15,1998

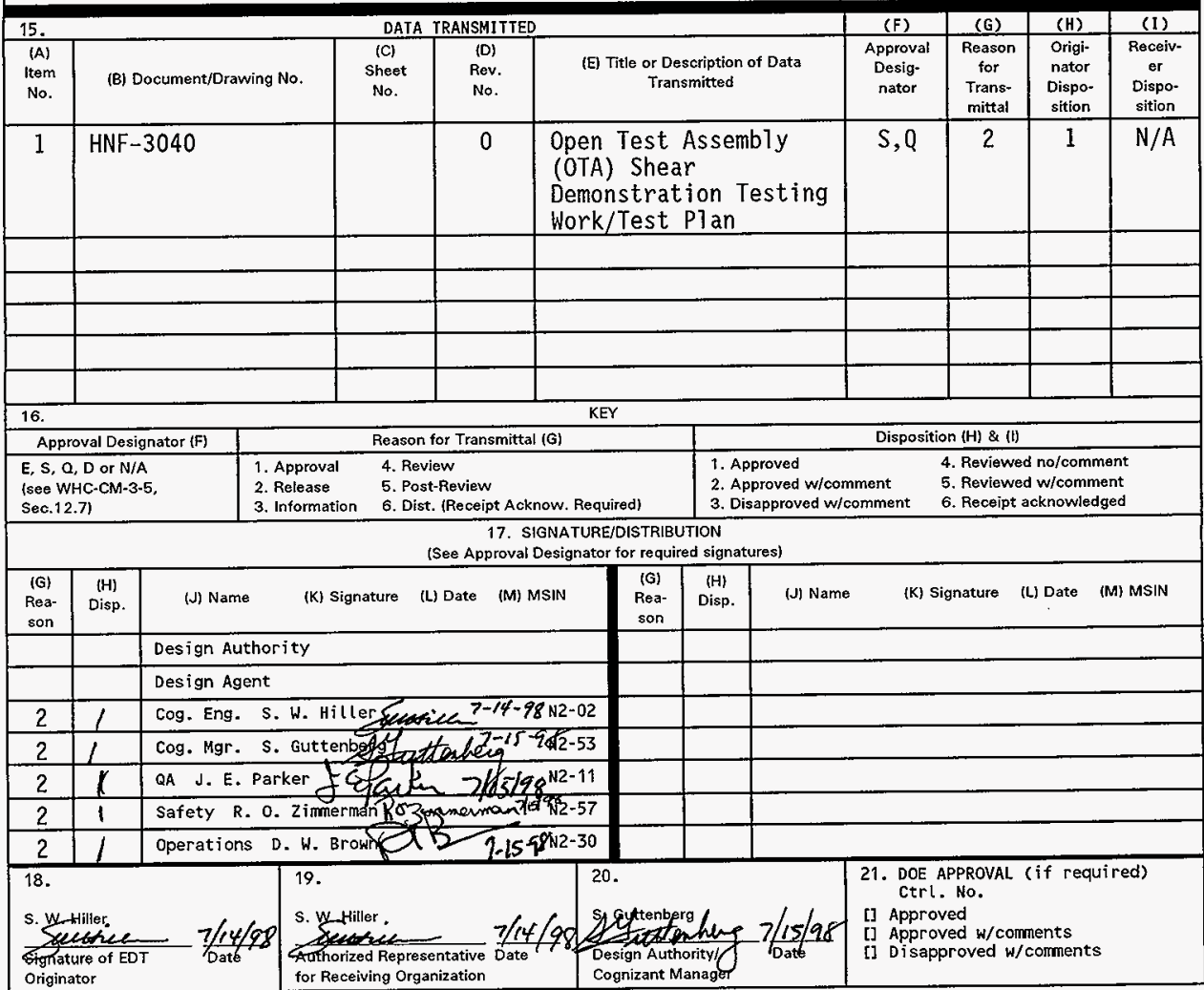


HNF-3040, Rev. 0

\section{Open Test Assembly (OTA) Shear Demonstration Testing Work/Test Plan}

S. W. Hiller

B\&W Hanford Co., Richland, WA 99352

U.S. Department of Energy Contract DE-AC06-96RL13200

$\begin{array}{lll}\text { EDT/ECN: } & 159332 & \text { UC: } 530 \\ \text { Org Code: } & 18220 & \text { Charge Code: } \\ \text { B\&R Code: } & \text { EX7002000 } & \text { Total Pages: } 10\end{array}$

Key Words: IEM Cell, Interim Examination and Maintenance Ce1], Open Test Assembly, OTA, Shear, OTA Shear.

Abstract: This document describes the development testing phase associated with the OTA Shear activity and defines the controls to be in place throughout the testing.

TRADEMARK DISCLAIMER. Reference herein to any specific commercial product, process, or service by trade name, trademark, manufacturer, or otherwise, does not necessarily constitute or imply its endorsement, recommendation, or favoring by the United States Government or any agency thereof or $i$ ts contractors or subcontractors.

Printed in the United States of America. To obtain copies of this document, contact: Document Control Services, P.O. Box 950, Mailstop H6-08, Richland WA 99352, Phone (509) 372-2420;

Fax (509) 376-4989.
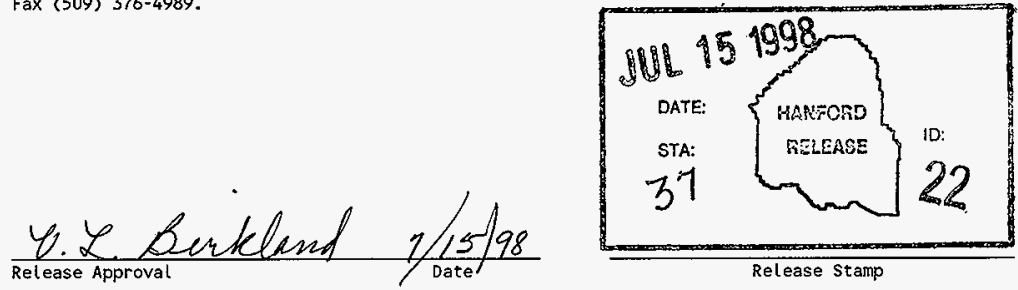

Release stamp 


\section{RELEASE AUTHORIZATION}

Document Number: HNF-3040, Rev. 0

Document.Title: Work/Test Plan

This document, reviewed in accordance with DOE Order 1430.1D, "Scientific and Technical Information Management," and DOE G 1430.1D-1, "Guide to the Management of Scientific and Technical Information," does not contain classified or sensitive unclassified information and is:

APPROVED FOR PUBLIC RELEASE
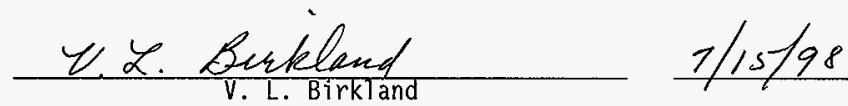

Lockheed Martin Services, Inc.

Document Control/Information Clearance

Reviewed for Applied Technology, Business Sensitive, Classified, Copyrighted, Export Controlled, Patent, Personal/Private, Proprietary, Protected CRADA, Trademark, Unclassified Controlled Nuclear Information.

LEGAL DISCLAIMER. This report was prepared as an account of work sponsored by an agency of the United States Govemment. Neither the United States Government nor any agency thereof, not any of their employees, nor any of their contractors, subcontractors or their employees, makes any warranty, express or implied, or assumes any legal liability or responsibility for the accuracy, completeness, or any third party's use or the results of such use of any information, apparatus, product, or process disclosed, or represents that its use would not infringe privately owned rights. Reference herein to any specific commercial product, process, or service by trade name, trademark, manufacturer, or otherwise, does not necessarily constitute or imply its endorsement, recommendation, or favoring by the United States Government or any agency thereof or its contractors or subcontractors. The views and opinions of authors expressed herein do not necessarily state or reflect those of the United States Government or any agency thereot. This report has been reproduced from the best available copy. Printed in the United States of America. 
Rev. 0, Page 1

OPEN TEST ASSEMBLY (OTA) SHEAR DEMONSTRATION TESTING WORK/TEST PLAN 
Table of Contents

$1.0 \quad$ Engineering Work Test Plan $\ldots \ldots \ldots \ldots \ldots \ldots \ldots \ldots \ldots \ldots \ldots \ldots \ldots$

2.0 Purpose $\ldots \ldots \ldots \ldots \ldots \ldots \ldots \ldots \ldots \ldots \ldots \ldots \ldots \ldots \ldots \ldots \ldots \ldots \ldots$

3.0 Test Purpose $\ldots \ldots \ldots \ldots \ldots \ldots \ldots \ldots \ldots \ldots \ldots \ldots \ldots \ldots \ldots \ldots \ldots \ldots \ldots$

$4.0 \quad$ Test Description $\ldots \ldots \ldots \ldots \ldots \ldots \ldots \ldots \ldots \ldots \ldots \ldots \ldots \ldots \ldots \ldots \ldots$

$5.0 \quad$ Control of Testing $\ldots \ldots \ldots \ldots \ldots \ldots \ldots \ldots \ldots \ldots \ldots \ldots \ldots \ldots \ldots \ldots$

6.0 Configuration Management $\ldots \ldots \ldots \ldots \ldots \ldots \ldots \ldots \ldots \ldots \ldots \ldots \ldots$

7.0 Personnel Qualification $\ldots \ldots \ldots \ldots \ldots \ldots \ldots \ldots \ldots \ldots \ldots \ldots \ldots \ldots \ldots$

8.0 Facility Considerations $\ldots \ldots \ldots \ldots \ldots \ldots \ldots \ldots \ldots \ldots \ldots \ldots \ldots \ldots$

$9.0 \quad$ Budget/Schedule. $\ldots \ldots \ldots \ldots \ldots \ldots \ldots \ldots \ldots \ldots \ldots \ldots \ldots \ldots \ldots$

10.0 Acceptance Criteria $\ldots \ldots \ldots \ldots \ldots \ldots \ldots \ldots \ldots \ldots \ldots \ldots \ldots \ldots$

11.0 Test Review $\ldots \ldots \ldots \ldots \ldots \ldots \ldots \ldots \ldots \ldots \ldots \ldots \ldots \ldots \ldots \ldots \ldots \ldots \ldots, 8$ 


\section{Open Test Assembly (OTA) Shear \\ Demonstration Testing Work/Test Plan}

\subsection{Engineering Work/Test Plan}

\subsection{Purpose}

Performance of the Full-scale Demonstration of the OTA Shear Components at the 309 Building IEM Cell Training Facility

\subsection{Test Purpose}

The OTA Shear Program provides equipment that is needed for the processing of 40 foot long, sodium wetted, irradiated core components previously used in the FFTF reactor to monitor fuel and materials tests. There are currently 15 of these OTA test stalks located in the Test Assembly Conditioning Station (TACS) inerted vault. These need to be dispositioned for a shutdown mission to eliminate this highly activated, high dose inventory prior to turnover to the ERC since they must be handled by remote operations. These would also need to be dispositioned for a restart mission to free up the vault they currently reside in.

The waste handling and cleaning equipment in the IEM Cell was designed and built for the handling of reactor components up to the standard 12 foot length. This program will provide the equipment to the IEM Cell to remotely section the OTAs into pieces less than 12 feet in length to allow for the necessary handling and cleaning operations required for proper disposition.

Due to the complexity of all operations associated with remote handling, the availability of the IEM Cell training facility, and the major difficulty with reworking contaminated equipment, it was determined that preliminary testing of the equipment was desirable. This testing activity would provide the added assurance that the equipment will operate as designed prior to performance of the formal Acceptance Test Procedure (ATP) at the IEM Cell. This testing activity will also allow for some operator familiarity and procedure checkout prior to actual installation into the IEM Cell. This development testing will therefore be performed at the conclusion of equipment fabrication and prior to transfer of the equipment to the 400 Area.

\subsection{Test Description}

The objective of this full-scale demonstration test is to ensure the newly developed OTA shear and supporting equipment performs per design. This includes functional checks; interface checks, demonstration of remote operation and initial procedure validation. This demonstration activity uses a graded approach to minimize cost and schedule and at the same time provide high confidence that the equipment will meet its intended use in the FFTF IEM Cell. 
HNF-3040

Rev. 0, Page 4

The IEM Cell Training Facility (IEMCTF) in the 309 Building has been used many times over the last 15 years to confirm equipment operations, check-out operating procedures and perform operator training of very complex, one-of-a-kind equipment required for the unique activities the IEM Cell is called upon to support. The major structures are similar to the actual IEM Cell and only a few minor modifications are required to support the OTA Shear Demonstration.

It is the intent of this testing to use all of the major components that are part of the OTA Shear equipment and actually demonstrate the shearing of two simulated, full-scale Materials Open Test Assemblies (MOTAs). The only major item not being tested is the Ident 26 OTA Receiving fixture. This support fixture attaches to Ident 26 (the multipurpose elevator in the IEMC) and is used to hold the OTA while it is being sheared. It was decided that this item would not be tested during this demonstration due to the expense required to mock-up the Ident 26 elevator that this would be attached to, and that its function and design is fairly simple as a support fixture. Accordingly, this item will be deferred until the actual ATP is performed at the IEM Cell and that the small risk of it not functioning properly during the ATP was accepted by the facility. The only remaining item not tested is the Ident-26 Elevation Index device. Again, because the training facility does not have a mocked up Ident-26, it would not be feasible to perform the necessary testing at 309 . The device will have some preliminary checks performed at the IEM Cell to confirm its ability for transfer into and out of the IEM Cell Small Tools Transfer Lock and attachment to Ident 26. Due to the simplicity of this device it is again agreed that no further checkout is required prior to the formal ATP at the IEM Cell.

Due to the limitations of the IEM Cell Training Facility, not all interfaces can be checked during this full-scale demo. Where feasible, simulated equipment has been provided to give an initial check of interfaces. All critical interfaces will have checks made that will give high confidence that the equipment will properly interface with the actual in-cell hardware. Interfaces which will be simulated are: the interface and operation by the Pedestal Mounted Manipulator (simulated by hands on operations); the fit of the Cut Part Catcher into the Ident-61 Waste Container Storage Fixture (simulated by the Cut Part Catcher Support Fixture); the fit of the shear into the Shielded Cell Transfer Container (SCTC), simulated by the mocked up SCTC cask enclosure; OTA and OTA cut piece handling throughout the shearing, washing and final storage processes (simulated by mocked up MOTA assemblies); and the fit of the wash basket into the Sodium Removal System T-100 (simulated by the mocked up T-100). The other interface checks will be using identical IEM Cell equipment or the actual OTA Shear equipment.

The testing will include, but not be limited to the installation, operation and removal of:

1. the OTA shear and the associated hydraulic pump unit

2. the Cut Part Catcher

3. the SRS Cut Part Wash Basket

4. the OTA Shear Restraint Bar System

5. the OTA Cut Part Grapples 
6. the Ident $116 \mathrm{D}$ Pedestal/Insert

7. the MASF Supporting Equipment

Due to the uncertain future mission of FFTF and the availability of other equipment, the schedule for actual testing in the IEMC is not well defined. Therefore the current plan is to leave all the equipment installed and de-energized in the IEMCTF at the completion of the demonstration activity. This will allow formal training to be performed at the IEMCTF by the FFTF Examination and Decontamination Services (EDS) Operations personnel, just prior to moving the equipment to FFTF for installation, formal testing by ATP, and normal operation. Should a change in mission or planning determine that this equipment will either not be used, or not be needed for several years, FFTF Engineering will take the lead to place the equipment into proper warehouse storage or other appropriate disposition, as necessary. It is understood that this would also be a mutual agreement with the 309 Building administration as the availability of the building may change requiring either relocation or storage of these items.

\subsection{Control of Testing}

The demonstration test will be controlled by work packages that will be prepared, approved and issued per FFTF administrative procedure A-28, FFTF WORK MANAGEMENT PROCESS. The primary procedure will consist of two parts. The first will be the test sequences and the second will be an attached EDS Operations Special Procedure (ESP) containing the generic installation, operating and removal instructions for each piece of equipment. The ESP will be prepared per FFTF administrative procedure A-25, FFTF_OPERATIONS/EDS SPECIAL PROCEDURES, and will be the basis for the actual FFTF operating procedures. Other work packages may be used for discreet activities needed to support the primary work package.

During the performance of the testing there will be a single Person in Charge (PIC) identified as responsible for the testing. Although various cognizant engineers will be involved as their specific hardware is tested and a Lead Engineer (LE) from EDS Operations will direct the operators, it will be clear and reiterated each day that the PIC has the overall responsibility for performance of the testing and all direction will come through the PIC.

The work package will be controlled per standard work control practices that will require an approved WCN for any changes in scope to the work document. Editorial changes or enhancements to the operating instructions for clarification can be added by pen-and-ink change to the work package ESP. All changes will be in red ink and approved by initials of the PIC and LE, with the date and time of the change/comment. To allow for the resolution of testing problems or scheduling issues, the actual sequence of testing can be performed out of sequence per PIC direction to best utilize the available resources. The Cognizant FFTF Engineering Manager (S. W. Hiller) will resolve all questions, conflicts or issues regarding the applicability of these requirements. 
All of the OTA Shear equipment has been designated as Safety Category General Services (GS).

\subsection{Configuration Management}

Configuration management for this activity will be controlled in several ways. HNFPRO-442, Development Control Requirements will be followed for all phases of this activity. The control of drawings will fall into two different categories. Those being equipment for Facility Use (future use at FFTF to perform or support the shearing activity) and that equipment for Non-Facility Use (equipment to support 309 testing only [simulates equipment at FFTF] which will remain at the 309 Building or further dispositioned at the end of testing).

"Facility Use" equipment will be controlled in one of two ways:

1. Released Drawings - this method is the preferred method and most direct means of configuration control. It consists of completing the design activity, issuing a released drawing or an ECN to a released drawing, and then fabrication per the released drawing.

2. Development Control Drawings - this method is used when the complexity and/or interfaces are not clearly defined or as well known and therefore the drawing will be preliminary (marked "development control") and red-lined during fabrication, and possibly the initial development testing phases, before the drawings will have the redlines incorporated and the drawings released. Per the requirements of HNF-PRO442 , these drawings will require final release before the equipment can be accepted at the FFTF for installation into the facility.

A variation on this will also be used for some items fabricated at the 400 Area Mechanical Shop. These items will be built to released work packages per FFTF Administrative Procedure A-28, FFTF WORK MANAGEMENT PROCESS. The process is identical in concept, with the major difference being a more formal means of change control. The fabrication work package will be issued with sketches as part of the released package. Changes that are required during the fabrication phase will be made by an approved WCN to the work package that will revise or replace the sketch. This provides a means for approvals by other disciplines as deemed necessary during the fabrication process. Again, once the equipment is shown to demonstrate correct functionality, an official drawing will be released and is required prior to installation at FFTF. The Work Package sketches will be identified as "Development Control" per HNF-PRO-442.

"Non-Facility Use" equipment will be controlled as follows:

Several items are required to be fabricated to allow "prototypic" testing to be performed in the IEMCTF at the 309 Building and are specific to that location. Most of these are of the support fixture or positioning fixture nature and will be disposed of or 
disassembled/excessed at the completion of the 309 activity. These items were all built to sketches in approved and released work documents. There will be no drawings formally issued and released for any of these items. As required in HNF-PRO-442, each item will be identified as "not for facility use" during its time of use at the 309 Building training facility.

\subsection{Personnel Qualifications}

The remote operations of this equipment will be performed by qualified EDS Operations personnel. These operators will also be IEMCTF qualified. They will work directly under the guidance of a certified EDS Operations LE. The LE will receive his instructions and guidance from the Engineering PIC responsible for the testing.

The Engineering PIC responsible for the testing will be a qualified FFTF PIC responsible for the day to day performance of the demonstration testing. He will be responsible for performance of the daily Pre-job Brief, and will ensure that the test procedure requirements are followed. The Engineering PIC will have overall responsibility for all aspects of the testing and all operations that are performed. It will be clear that the PIC alone gives direction to the EDS LE and directs all operations at 309 facility. The PIC will also ensure that Test Log entries are made detailing any problems, questions, issues or considerations that arise during the testing. Closeout of the testing activity will ensure that each entry is resolved to the satisfaction of Engineering and EDS Operations.

All hoisting and rigging will be performed by personnel qualified to the Hanford Site Hoisting and Rigging Manual, DOE-RL-92-36.

The overall Design Authority (DA) for the IEM Cell Shear is PW McGuinness. All changes or revisions to its operation will be approved by the DA. Other engineers responsible for the design of some of the interfacing hardware will be involved in the testing and will document the acceptability of its performance.

\subsection{Facility Considerations}

Impact to other programs:

There are no other activities in progress either now or planned that would impact the performance of this demonstration activity or that would be impacted by this activity.

\section{Safety Considerations:}

Hoisting and rigging operations and OTA Shear cutting operations are the main areas of concern. All hoisting and rigging will be performed per the requirements of the site hoisting and rigging manual with the appropriate Personal Protective Equipment (PPE) required for normal hoisting and rigging operations. Due to the nature of remote testing using manipulators, there are occasions where the throat latch on the crane and rigging hooks will need to be positioned to an open position. This is an accepted practice in the 
hot cell and during these activities, all personnel will be cleared from the area prior to any lifts or moves with the latch disabled.

The work package controlling the demonstration activity will specify that hard hat use is required when entering the cell area, as well as clearing of personnel from the cell area during any cutting/shearing operations. This will also be covered in the Pre-job briefs held at the beginning of each day of testing.

Personnel involved in the testing at the 309 Building will receive facility orientation to familiarize them with the appropriate responses and building requirements and limitations. Those that will be involved with only short duration activities or observations can be escorted.

All work performed at the 309 facility will be covered by approved work packages released through the 300 Area work control system.

\subsection{Budget/Schedule}

This activity (Task Code 1B1A0A020B) is currently loaded in the FY98 Resource Loaded Schedule for FFTF. Costs will be collected under TPCN Code: B1054. It is expected that the testing will be performed during July and August of 1998.

\subsection{Acceptance Criteria}

The nature of this demonstration activity is to prove the functionality of each new major component that will be used for the shear activity. The testing will also include interface checks, checks for adequacy of remote operations, and preliminary procedure checks. The acceptance for each item will be jointly determined by the engineering and operations organizations and signatures in the work package will be made at each step by the appropriate engineer and the EDS LE. Discrepancies, deficiencies, etc. will be recorded in the test log maintained throughout the demonstration activity. The test log will be added to the work document to become part of the closed package. A final problem list with the resolutions will be included in a memo issued by Engineering with Operations concurrence.

\subsection{Test Review}

A test $\log$ will be maintained throughout the demonstration activity. All personnel involved in the testing will be encouraged to make entries into the test log. The PIC will be required to make entries daily for each major activity and detail any problems encountered. At the completion of the demonstration activity, both Engineering and Operations will then review the test $\log$ and marked up work document as a minimum. An internal memo, signed by both Engineering and EDS Operations, will then be issued confirming that all identified problems were satisfactorily resolved prior to declaring the testing complete. Rework and retesting will be performed as required to ensure appropriate resolution. 


\section{INFORMATION CLEARANCE FORM}

\begin{tabular}{|c|c|c|}
\hline \multicolumn{2}{|c|}{ A. Information Category } & B. Document Number HNF-3040, Rev. 0 \\
\hline$\square$ Abstract & $\square$ Journal Article & c. Title \\
\hline$\square$ summary & $\square$ internet & Open Test Assembly (OTA) Shear Demonstration Testing Work/Test \\
\hline$\square$ Visual Aid & $\square$ software & Plan \\
\hline$\square$ Full Paper & {$[\mathrm{X}$ Report } & \\
\hline J Other & & \\
\hline
\end{tabular}

E. Required Information

1. Is document potentially Classified? $\mathrm{X}$ No $\square$ Yes (MANDATORY) Is docyment potentially Classified?

If Yes

$$
\text { ADC Signature Required }
$$

$\square$ No $\square$ Yes Classified

2. Internal Review Required?

If Yes, Document Signatures Below

\No $\square$ Yes

Counsel

Program

3. References in the Information are Applied Technology

Export Controlled Information
4. Does Information Contain the Following: (MANDATORY)

a. New or Novel (Patentable) Subject Matter? $\quad \mathrm{X}$ No $\square$ Yes

If "Yes", Disclosure No.:

b. Information Received in Confidence, Such as Proprietary and/or Inventions?

$[X$ No $\square$ Yes if "Yes", Affix Appropriate Legends/Notices.

c. Copyrights? $\square$ No $\square$ Yes If "Yes", Attach Permission.

d. Trademarks? $\square$ No $\square$ Yos If "Yes", Identify in Document.

5. Is Information requiring submission to ost'? $\square$ No $\square]$ Yes

if Yes $U C-\underline{530}$ and $B \& R-\underline{E X 7002000}$

6. Release Level? $\square$ Public $\square$ Limited

7. Charge code $\frac{\mathrm{Ft} 803-\mathrm{B} / 1 / 64}{7-15-98}$

F. Complete for a Journal Article

1. Title of Journal

G. Complete for a Presentation

1. Title for Conference or Meeting

2. Group Sponsoring

3. Date of Conference

5. Will Information be Published in Proceedings? $\square$ No $\square$ Yes

4. City/State

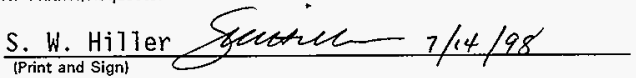

6. Will Material be Handed Out? $\square$ No $\square$ Yes

\section{(Print and Sign)}

I. Roviewers

Yes Print

Responsible Manager

S. Guttenberg fy tuttenlere (Print and Sign)

Signature

Public Y/N (If N, complete J)

General Counsel

Office of External Affairs

DOE-RL

Other

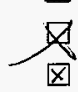

R.A.A.

$\operatorname{lngint}$

D.A. Gautt, Apprisel Tehindlyy officer
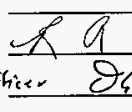

OCa

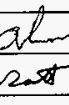

th

$D$ i

$7 / 15 / 58$

Other

J. If Information Includes Sensitive Information and is not to be released to the Public indicate category below.

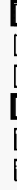

Applied Technology

$\square$ Personal/Private

$\square$ Protected CRADA

$\square$ Proprietary

$\square$ Business-Sensitive

[ Predecisional

$\square$ Export Controlled

$\square$ Procurement-Sensitive

$\square$ Patentable

$\square$ Other (Specify)

$\square$ UCNi

Information Clearance Approval

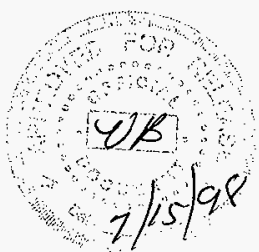

